\title{
Realities and prospects of using green technologies in Kazakhstan
}

\author{
Galiya Sansyzbayeva ${ }^{1}$, Laura Ashirbekova ${ }^{1 *}$, Kuralay Nurgaliyeva ${ }^{1}$, Zhuldyz Ametova $^{1}$ \\ and Arailym Asanova ${ }^{1}$
}

${ }^{1}$ Al-Farabi Kazakh National University, al-Farabi Ave. 71, 050040 Almaty, Republic of Kazakhstan

\begin{abstract}
The particular relevance of the study of issues related to global crises is determined by the fact that although they affect the whole of humanity as a whole, the least economically and socially protected layers of the population in the whole world suffer from their consequences. That is why the key concepts of a green economy are natural capital and the ecosystem services it provides. The main priorities of the green economy concept are to increase the well-being of society with minimal impact on the environment. The article discusses the theoretical aspects of the implementation of the concept of "green" economy in Kazakhstan. The main directions of the "green" economy are highlighted and the results of the transition to a green economy are analyzed. The main stages of development of green economy in Kazakhstan are described. The problems of Kazakhstan's transition to a "green" course of economic development are studied and the need for innovative approaches in the development of green technologies in the country is substantiated.
\end{abstract}

\section{Introduction}

The change in technological development and diversification of production towards "green technologies" occurred at the end of the XX century and affected all existing and newly developed technologies. In this regard, developed countries set themselves the task and adopt national and international programs to protect the environment and human beings from themselves, realizing that the time has come to save the planet from themselves, unreasonably, excessively exploiting and loading nature. The answer to these challenges is a new area of science and practice called "green technologies". There is no single definition of "green" or environmentally friendly technologies. The General approach assumes the achievement of their main goal-reducing the negative impact on the environment by reducing the amount of resources consumed, reducing waste up to their full return to production through progressive processing, technological processes, principles and mechanisms that "work" in nature, increasing the

* Corresponding author: turar200480@mail.ru 
efficiency of production and life, improving the properties of materials from the point of view of environmental safety.

\section{Literature review}

The term "green economy" was first used in the work of the Project for a Green Economy, which is a programmatic text for proponents of this still emerging discipline, which focuses on the sustainable development economy [1].

According to the green economy premises different natural assets delivered by ecosystems (i.e. natural capital) provide fundamental benefits for the economy and society, which are often invisible or disregarded [2].

Rational use of natural resources is a fashionable topic. For the first time, the modernization of economic models in favor of their environmental friendliness began in the 70 s of the XX century. After the oil crisis in 1973, energy prices rose significantly. This has made the world think about energy efficiency, new technologies and renewable energy sources.Modern analysts pay great attention to "green" development, which contributes to sustainable economic growth on a new innovative basis that does not have a harmful effect on humanity, provides a transition to a smart economy by finding opportunities for the efficient use and conservation of natural capital, and reduces risks from global threats like climate change, the loss of ecosystem services and water scarcity.

There is no clear interpretation of the "green" economy among scientists and practitioners. For example, the United Nations environmental protection organization (UNEP) interprets the "green" economy as an economic activity that "increases the well-being of people and ensures social justice, while significantly reducing the risks to the environment and impoverishment of nature" [3].

R. K. Sagieva and A. S. Zhuparova interpret the green economy as an economy that relies on resource-saving and environmentally friendly production, increases the well-being of people and reduces risks to the environment. At the same time, they emphasize that while there is an obvious need to move to an economic model that will improve human well-being while preserving resources and not exposing future generations to significant environmental risks, the transition to a "green economy" is associated with numerous problems. In particular, issues related to regional characteristics, prerequisites and opportunities for the transition to a "green economy" have not yet been worked out. Comprehensive studies are needed that would take into account the individual specifics of individual territorial complexes of Kazakhstan for the transition to green economic growth: natural and climatic conditions and resources, the availability of labor (including intellectual) potential, etc. [4].

\section{Methodology}

Kazakhstan scientists B. K. Esekina, R.K. Sagieva C.T. Rakhimbekova, A. Zhidebekkyzy and others made a significant contribution to the development of the theory and practice of green technologies development. The research is based on the use of scientific methods: generalization from the particular to the general and from the general to the particular, analysis, forecasting, system, situational; also used techniques of structural and functional, subject-object, expert, statistical analysis. In the course of writing the article, various sources of literature were used: scientific literature, analytical materials and program documents of the country.

In modern science, there are several methodological approaches used to understand the green economy. This is a technological, industrial, and moral and environmental issue. 
According to the technological approach, the green economy is understood as the transition of all industries to technologies that ensure the creation of environmentally friendly industrial and food products. This interpretation is not fundamentally different from the interpretation of the concepts of "environmental management" or "environmental economy". The industry approach assumes an understanding of the green economy as the production of environmentally friendly food products or the development of individual industries on "green" principles. The moral and environmental approach is linked to the environmental movement for nature conservation and the solution of the problem of poverty. This was reflected not only in the documents prepared for the Rio+20 Conference, but also in the report of the United Nations environment Programme (UNEP) "Towards a green economy: ways to sustainable development and poverty eradication" (2011) [5].

The industry approach we have chosen to understand the green economy considers the lowcarbon economy, the environmental economy, the economy of nature management, energy conservation, and green technologies. Green energy is often considered to be based on energy savings and the use of renewable energy sources. The program documents of the Republic present priorities for the introduction of "green", low-carbon technologies and reducing the energy intensity of the national economy by $25 \%$. Within the framework of the Concept for the transition to a "green" economy, the tasks are set to achieve the share of renewable energy sources (RES) in the country's total energy balance by $2020-3 \%$, by $2050-50 \%$, which will reduce greenhouse gas emissions in the energy sector to the level of developed countries [6].

\section{Results and Discussion}

While national incomes are rising, environmental sustainability indicators are declining worldwide. A 2010 world wildlife Fund (WWF) report shows that the living planet index is down 30\% from 1970.

And the ecological footprint of mankind has almost doubled. By 2030, we may simply not have enough resources to sustain our current standard of living.

Ecological footprint-a measure of human impact on the environment, which allows you to calculate the size of the surrounding area, necessary for the production of environmental resources consumed by us and the absorption of waste. As the negative impact on the environment worsens, most countries of the world community have taken a course to develop a "green" economy. A green economy is needed to conserve natural capital, ecosystems and biodiversity while generating income and employment growth. This concept appeared as part of the concept of sustainable development.

Sustainable development is defined as one in which the needs of current generations are met without compromising the consumption opportunities of future generations. This basic formulation appeared in 1987 in the report "Our common future" of the UN Commission on environment and development. The essence of sustainable development is in the interconnected and proportional development of the three components of the state system: economic, social and environmental.

Kazakhstan, one of the first countries in the world, at the state level adopted a strategic document for the transition to a "green" economy - the Concept for the transition of the Republic of Kazakhstan to a "green economy" [7].

Table 1 presents the potential benefits of the development of the green economy, which emphasizes the need for the country to switch to green production growth, which means taking into account the environmental condition of the environment.

Table 1. Potential Benefits of Green Growth Policies. 


\begin{tabular}{|c|c|c|}
\hline $\begin{array}{l}\text { Varieties of } \\
\text { Benefits }\end{array}$ & Policy directions & Indicator Examples \\
\hline Environmental & Environmental improvement & $\begin{array}{l}\text { Reducing greenhouse gas emissions, using } \\
\text { recycled materials, etc. }\end{array}$ \\
\hline \multirow[t]{3}{*}{ Economic } & \multirow[t]{3}{*}{$\begin{array}{l}\text { Improving wealth through } \\
\text { increased income }\end{array}$} & $\begin{array}{l}\text { Increase in factors of production (physical, } \\
\text { human and natural capital) }\end{array}$ \\
\hline & & $\begin{array}{l}\text { Accelerate the application of innovation by } \\
\text { correcting market failures in the } \\
\text { application of knowledge }\end{array}$ \\
\hline & & $\begin{array}{l}\text { Improving efficiency by adjusting for } \\
\text { failures in a non-environmental market }\end{array}$ \\
\hline \multirow[t]{2}{*}{ Social } & \multirow{2}{*}{$\begin{array}{l}\text { Improving welfare through } \\
\text { distributional effects, reducing } \\
\text { volatility (volatility, } \\
\text { variability) and other social } \\
\text { indicators }\end{array}$} & $\begin{array}{l}\text { Improving resilience to natural disasters, } \\
\text { commodity price volatility, economic } \\
\text { кризисам }\end{array}$ \\
\hline & & Job Creation and Poverty Reduction \\
\hline
\end{tabular}

Currently, the Republic of Kazakhstan does not adequately ensure the benefits of a green growth policy, although much is being done: wind and solar power plants are being built, public transport is changing to environmentally less harmful for the population, and the government is trying to introduce a policy of efficient use of natural resources.

Target indicators, norms and measures of the "green" economy are included in legislative acts and policy documents of the Republic of Kazakhstan, are guidelines for all levels of government and all sectors of civil society in the transition to a green economy [8].

According to the Organization for economic cooperation and development (OECD) classification, green technologies cover the following areas:

- General environmental management (waste management, water and air pollution control, land restoration);

- production of energy from renewable sources (solar energy, biofuels, etc.), mitigation of climate change, reduction of harmful emissions into the atmosphere, improvement of fuel efficiency, as well as energy efficiency of buildings and household appliances.

If we expand this compressed formula, we get that "green technologies" essentially cover all areas of human activity and are aimed at:

- Sustainable development of modern society for the benefit of future generations with the solution of global problems: prevention of resource depletion, establishment of reasonable environmental management, improvement of demography, elimination of production toxicity;

graves grave-production of non-toxic products in a closed cycle: production-disposalnew production (from birth to birth - "cradle to cradle", instead of the current "grave to grave" - from grave to grave);

- Maximum, up to zero, reduction of waste due to innovations in technologies and consumption structure;

- Fundamental modification of harmful industries and their replacement with harmless ones using natural technologies created by nature over millions of years;

- Replacement of non-renewable natural resources with alternative renewable sources of raw materials and energy;

- Elimination of the use of harmful synthetic chemicals in agriculture, introduction of biotechnologies in agriculture, animal husbandry and processing of agricultural products.

Currently, "green technologies" are being implemented in the entire chain of companies ' activities, including, in addition to production, consumption, management and methods of organization of production, in order to solve global challenges for the sustainable development of modern and future society, namely:

- Modification and replacement of hazardous industries; 
- Development of new alternative energy and new fuels;

- Search for new approaches to safe and affordable food and water;

- Protection from pollution of the atmosphere, soil, fresh water and the world ocean;

- Reasonable regulation of demographics.

The concept of green growth is particularly important for Kazakhstan because it focuses on:

* Sustainable economic growth. Kazakhstan's economy has low diversification rates, where oil and gas, mining and agriculture play a key role in economic growth. At the same time, consumer goods and commodities occupy a significant share of Kazakhstan's exports. Foreign trade and economic diversification are constrained by a number of factors, including inefficient logistics and underdeveloped infrastructure, which play an important role in the region because Kazakhstan is landlocked and dependent on neighboring countries for access to world markets. Poor or deteriorating infrastructure leads to high costs and losses, especially in transport and power transmission.

* Renewable natural capital (i.e. drinking water and sustainable agriculture) and clean physical capital (e.g. solar panels, wind turbines and green public transport systems). Kazakhstan continues to face the historical challenges of access to drinking water, production and distribution of electricity. In addition, unsustainable agricultural practices and the consumption of natural resources have exacerbated some environmental problems. Thus, Kazakhstan has witnessed an environmental disaster in the Aral sea region and in the near future will face serious risks to the safety of water supply $[9,10]$.

* Developed human and social capital (e.g. equal access to opportunities and social security). Despite the relatively high human development index, a large proportion of the region's population is unemployed or employed in the informal sector, and poverty remains high, especially in rural areas. Moreover, the quality of life in the region is falling due to lack of access to basic services, electricity, and in some regions, to drinking water. Access to basic social services and necessary infrastructure is complicated by low population density and a large proportion of the population living in rural areas.

Today it is possible to allocate the following types of advantages of use of green technologies for Kazakhstan:

- Possibility to reduce water supply costs up to $75 \%$;

- Getting hot water from solar collectors for free;

- Increase the yield of grown products up to $60 \%$;

- Reduction of heating costs up to $50 \%$;

- Reduce lighting costs by up to $50 \%$;

- Reducing the cost of production through the use of green technologies.

"Green" technologies are used in agriculture and in the business environment. Kazakhstan has already implemented two projects that fully meet environmental criteria.

For example, in the small village of Arnasay, 30 kilometers from the city of Nur-Sultan, a Center of "green" technologies appeared in 2015. It develops 35 innovative projects in the field of organic farming, resource conservation. 168 houses in the village use drip irrigation, 5 houses have pyrolysis furnaces. Arnasay has a year-round greenhouse where different heating sources are combined. In summer, a children's tent camp worked in the village. The tents were illuminated by solar panels [11].

Today, green technologies are a global trend, and Kazakhstan has approved a Concept for the transition to a" green "economy [12]. There are indicators of achieving goals by a certain year. This document is a fundamental guideline for our country. 


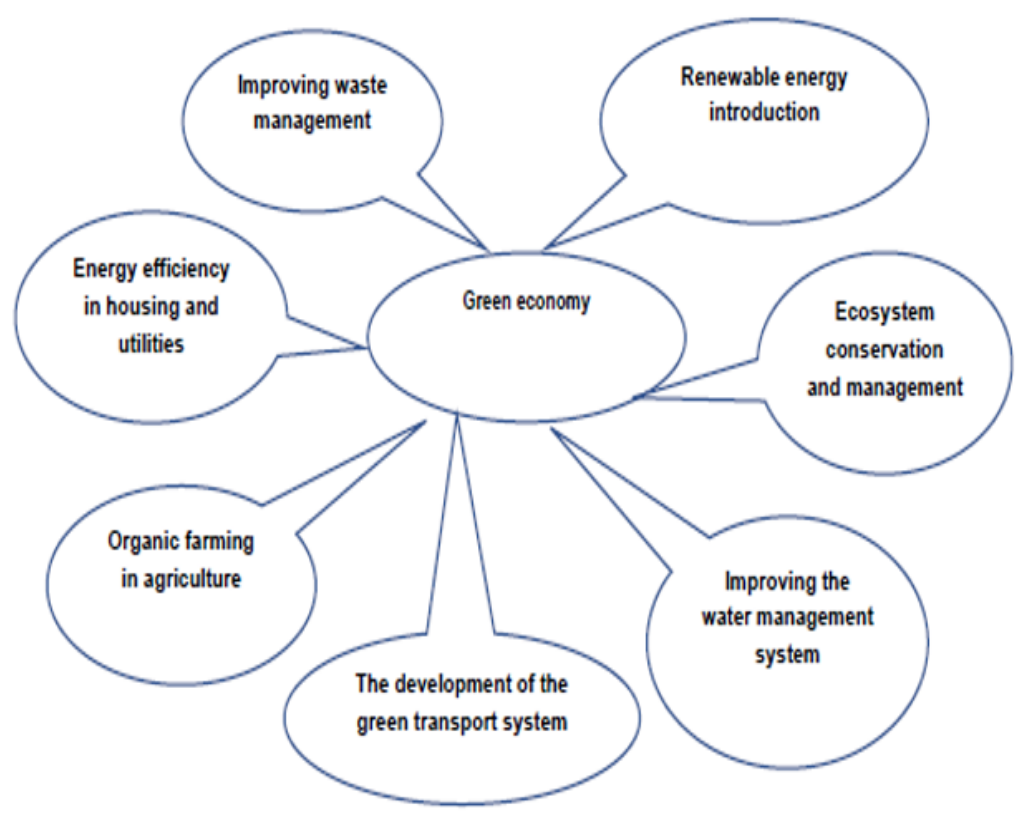

Fig.1. System of directions in green economy

Among the prerequisites for the transition to a "green economy" is a set of serious justifications for the transition to a "green course" and lays the foundations for deep systemic reforms to improve the welfare of the quality of life of the population of Kazakhstan and the country's entry into the number of 30 most developed countries in the world $[13,14]$.

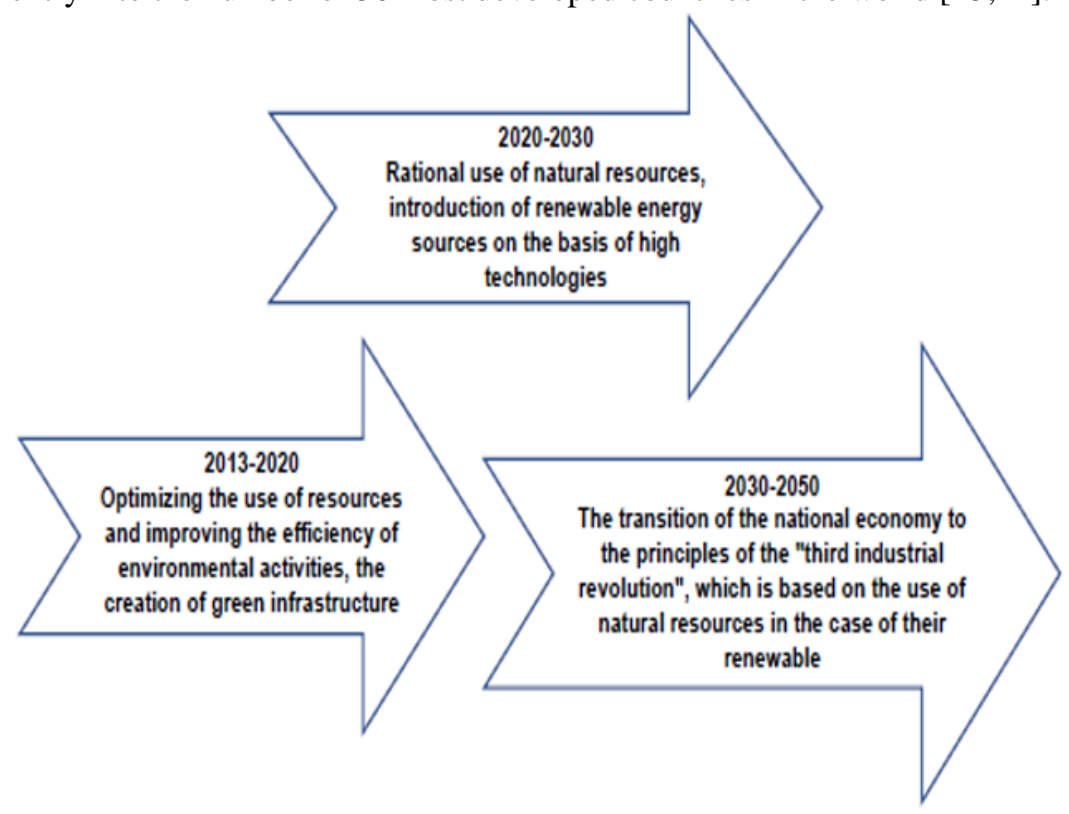

Fig.2. Stages of development of "green" economy in Kazakhstan 
Considerable attention is paid to social and regional development, especially with regard to modern agricultural practices and the conservation of water and land resources. These two problems are the most important from the point of view of preservation of national ecosystems.

As a result of rapidly increasing water demand and declining sustainable water supplies, a set of pre-emptive actions is required, and the threat of water scarcity and inefficient water management can become a major obstacle to a country's sustainable economic and social development. No less relevant are the topics related to the development of sustainable and high-performance agriculture. The Concept provides a serious qualitative and quantitative analysis of the state in comparison with foreign countries, which shows a whole range of problems that need to be solved in the coming years according to the laid indicators. In this regard, it is necessary to develop a whole range of information for target groups, which should include not only farmers, but also government agencies and financial institutions. Successful foreign and national experience on "green business cases"should be included in the content of information.

The energy intensity of GDP depends on GDP trends and energy consumption patterns. Compared to the "green" and basic scenarios, the potential for transition to energy-efficient technologies is undoubtedly high. And here there are a number of obstacles, which will help to solve, including awareness in this area [15].

The transition to the large-scale implementation of RES (renewable energy sources) by $50 \%$ is planned as the achievement of one of the main goals of the Strategy -2050 [16].

The current situation in the field of waste management does not meet sanitary standards, there is no required infrastructure and technology, organizational and legal framework are in the nascent state. All this together requires hard work, experience which the country does not, accordingly there is a need for serious information work with the assistance of international practices, aimed at the awareness of the responsibility of the entire population, including large users, for the improvement of the ecological situation and reduction of technogenic impact on the environment [17].

Air pollution is a serious environmental problem in industrial and urban areas of Kazakhstan. Conservation and effective management of wildlife ecosystems is particularly relevant in the light of the "Tugan Zher" project, which is aimed at local, local objects and settlements. Kazakhstan is adopting the necessary laws, creating a regulatory framework corresponding to international standards for the implementation of the principles of the "green economy".

As international practice shows, the achievement of the planned result of this reform process is impossible without the existence of an effective mechanism of informing society in this area. Appropriate public information and active participation are essential for the consolidation of democratic principles and institutions of the country, ensuring civil control over the process of economic growth and environmental balance [5].

At present, there is still a weak understanding and interest on the part of society in the problems of the country's transition to a"green economy". This situation is caused by insufficient participation of responsible state institutions in the process of reforms in the field of "green economy" and, accordingly, insufficient media coverage of the processes taking place in this area.

The situation with the development of the "green" economy in the regions of the Republic is estimated by the following indicators:

- development of energy, including renewable energy and provision of energy to the population;

- condition of water supply and Sewerage, provision of the population with centralized water supply and sanitation; 
- management of production wastes and consumption, waste and recycling;

- development of organic and resource-saving agriculture, water-saving technologies in agriculture [18];

- state of the environment, reduction of air and water pollution;

- state of biological resources and development of forest, fish and hunting farms and development of ecological tourism.

The analysis of the implementation of the Concept of transition of the Republic of Kazakhstan to the "green economy" showed the correctness of the selected areas and the achievability of the established indicators. At the same time, the country is successfully contributing to the achievement of the new sustainable development goals set by the UN General Assembly in September 2015. For Kazakhstan the transition to a green economy in the period 2015-2017 is characterized by the following main results achieved:

The share of water users with permanent access to the Central drinking water supply system increased in cities from $55 \%$ to $88 \%$, in rural settlements from $11 \%$ to $52.3 \%$, and to water disposal systems-in cities from less than $50 \%$ to $91 \%$, rural settlements from $11 \%$ to more than $20 \%$ [19].

As a result of the use of water-saving technologies, the productivity of water resources in agriculture has increased almost in 1.5 times. The total productivity of labor in agriculture has increased by almost 2.5 times, and the yield of grain by almost $15 \%$.

In fact, the energy intensity of GDP decreased by $14.1 \%$ in 2014 but then increased slightly again. The law of the Republic of Kazakhstan "On energy saving and energy efficiency" establishes the legal and economic basis for energy saving and energy efficiency. For example, the construction provides for the mandatory use of energy-saving materials, energy metering devices, automated regulation of heat consumption. In multi-apartment houses use of energy-saving materials, accounting of energy, cold and hot water, gas, as well as automated systems of heat consumption. Acceptance of the new objects which are not equipped with devices of the account of energy resources is not allowed. For organizations included in the state energy register, a mandatory energy audit is provided [20, 21].

The share of RES has increased more than 2 times since 2012 and the expected share of RES in the total volume of electricity production in the Republic of Kazakhstan for 2017 amounted to about $1 \%$. At the moment, there are 50 existing renewable energy facilities with a total capacity of 295.7 MW in the Republic. and investors ' interest in the implementation of renewable energy projects continues to grow. The law of the Republic of Kazakhstan "on support for the use of RES" guarantees free access to the electricity market for RES, as well as the unhindered, non-discriminatory and priority right to connect to the nearest point of the transmission network. The law also provides for fixed tariffs for RES and the provision of targeted assistance to individual consumers in the amount of $50 \%$ of the cost of installations for the use of RES [22].

The coverage of the population with waste disposal services increased from 59\% to $66 \%$ by 2017 . The share of waste disposal facilities that meet sanitary standards in the period from 2016 to 2017 increased from $11 \%$ to $15 \%$ [23].

The share of industrial waste processing increased from $24.9 \%$ to $29.4 \%$ during this period, and domestic waste-from $1.3 \%$ to $2.6 \%$. The regulatory framework for the introduction of collection, transportation, processing, disposal and disposal of solid waste has been created. Thus, amendments were made to the Environmental code on waste management, in particular [8]:

- the introduction of mandatory national standards to establish requirements for enterprises operating in the waste market is envisaged;

- a ban on the disposal of certain types of waste;

- Approved methodology for calculating the tariff for the collection and disposal of solid waste, including sorting and processing, providing for separate tariff for each operation; 
- extended obligations of manufacturers (importers) for passenger cars, tires, oils and batteries, and certain types of solid waste (containers, electrical equipment) have been introduced. This will contribute to the development of recycling of certain types of solid household waste: plastic, polyethylene, waste paper, glass and reduce the volume of buried waste by an average of $40 \%$. The area of forest land in Kazakhstan has been declining for many years and the long-term value of these assets has declined-especially as a result of illegal logging, forest fires and land reassignment. Only in recent years, a gradual increase in the forested area began from 12.4 million hectares in 2012 to 12.5 million hectares in 2017 , which amounted to $4.7 \%$ of the territory of the Republic. This was facilitated by reforestation and afforestation, which is carried out annually on an area of about 10 thousand hectares.

Of the regions, the best results in terms of a complex "green" indicator were shown by the cities of Republican significance - Almaty and Astana, as well as Zhambyl region. The lowest score was scored by Pavlodar, Karaganda and Aktobe regions (about 5 points) [24].

Other regions of Kazakhstan demonstrate an average level of environmental well-being.

Thus, the analysis of the implementation of the Concept shows that all the tasks set in the Concept will be fulfilled, and the targets will be achieved within the established time frame.

\section{Conclusion}

The analysis of international experience shows that a number of countries, including developing countries, show higher rates of progress in such areas of "green" economy as the introduction of renewable energy, energy efficiency and water efficiency, waste recycling, the introduction of organic agriculture and others. There are also emerging new policy approaches to the transition to a "green" economy, such as inclusiveness, circularity, green Finance and the nexus approach.

In this direction, the Concept of transition to a "green" economy will be updated.

The international center for green technologies and investments will promote innovative approaches. The activities of the Center will cover seven main areas of activity: transformation of the energy sector, sustainable urban development, development of "green" business, transfer and adaptation of "green" technologies and best practices, development of "green" financing, development of renewable energy.

In the Republic of Kazakhstan much is being done in the field of implementation of the Concept on transition to a "green" economy. The country has developed a register of "green" technologies, and many entrepreneurs can successfully apply them in their activities. Arnasay 's experience as a Green Technology Training Center is spread across regions of Kazakhstan, where more efficient use of renewable energy sources is observed, energy consumption is reduced, the efficiency of a number of agricultural facilities in the regions is increased, the green responsibility of schoolchildren is increased, innovative thinking of young people is developed.

In order to improve the development of the "green" economy in the Republic of Kazakhstan, it is necessary to increase the environmental responsibility of every citizen of Kazakhstan, and the Government of the country to look for ways to stimulate the attraction of investments in the development and use of "green" technologies.

\section{References}

1 Pearce et al, Blueprint for a Green Economy, (1989).

2 D. D'Amato, N. Droste, B. Allen, M. Kettunen, K. Lahtinen, J. Korhonen, P. Leskinen, B.D. Matthies, A. Toppinen. Journal of Cleaner Production 168 (716-734), (2017).

3 http://greenlogic.by/content/files/GREENTRANSPORT/UNEP90_RUS.pdf. 
$\underline{4}$ R. K. Sagieva, A. S. Zhuparova. Economic incentives for the development of the green economy in Kazakhstan. Bulletin Of The Treasury. A series of environmental. 2 (3), (38). (2013).

5 Navstrechu «zelenoy» ekonomike: puti k ustoychivomu razvitiyu i iskoreneniyu bednosti — obobschayuschiy doklad dlya predstaviteley vlastnyih struktur // YuNEP (2011).

6 A. A. Satybaldin, B. K. Esekina, N. K. Nurlanova, Paradigm of future energy: the way of Kazakhstan. THE ECONOMY AND THE ENVIRONMENT. PSE, (2017).

7 Kontseptsiya po perehodu Respubliki Kazahstan k «zelenoy ekonomike». Utverzhdena Ukazom Prezidenta Respubliki Kazahstan ot 30 maya 2013 goda (2013).

8 Ekologicheskii kodeks Respubliki Kazahstan ot 9 yanvarya 2007 goda № 212, obnovlennyi s izmeneniyami na 26.12.2019 (2019).

9 Global green new deal. The UNEP report. - March. - 42 p. [ER]. Mode of access: www.unep.org/greeneconomy (2009).

10 G. N. Sansyzbayeva, A. Zhidebekkyzy Agricultural Innovations for Sustainable Development: Analysis of Situation in Kazakhstan and Ways for Improvement. 2016 International Conference on Business and Economics (ICBE 2016). - Seoul, South Korea, July, 07-09. - p. 355-358 (2016).

11 Rahimbekova S. «Zelenyi put: Expo-2017 i «zelenaya» economika. Analiticheskii obzor. 2-e izd.- Astana: Glasir. - 276 p.(2018).

12 Kazakhstan: Dobrovolnyi natsionalnyi obzor Respubliki Kazahstan 2019 «O realizatsii povestki dnya do 2030 goda v oblasti ustoichivogo razvitiya». - Nur-Sultan: Ministerstvo natsionalnoi economiki RK, Institut economicheskih issledovanii RK. - 160 p. (2019).

13 E.V. Varavin, M.V. Kozlova, A.V. Shmakov. Otsenka ekologo-ekonomicheskogo razvitiya regionov Kazahstana i politika podderzhki «zelenoy» ekonomiki na regionalnom urovne. Vestnik KarGU, 2017 g.Karaganda.

14 A. Kozhakhmetova, A. Zhidebekkyzy, A. Turginbayeva, Z. Akhmetova. Modelling of project success factors: A cross-cultural comparison. Economics and Sociology. 12(2), 219-234 (2019).

15 A. Zhidebekkyzy, A. Trifilova, G. N. Sansyzbayeva. Organizational and Economic Mechanisms for Commercialization of Green Technologies in Kazakhstan// Vestnik KazNU (seriya ekonomicheskaya). - Almaty: Kazakh universiteti. - 1 (127), 13-22 (2019).

16 Strategiya «Kazakhstan - 2050: novyi politicheskii kurs sostoyavshegosya gosudarstva». Poslanie Prezidenta Respubliki Kazahstan N.Nazarbayeva narodu Kazakhstana ot 14 dekabrya 2012 goda (2012).

17 Threats to the country's Sustainable Economic Development: a Case Study. Journal of Security and Sustainability Issues https://doi.org/10.9770/jssi.2018.8.1(10).

18 V. V. Grigoruk, E. V. Klimov. Razvitie organicheskogo selckogo hozyaistva v mire b Kazakhstane /Pod obshchei redaktsiei doktora selskohozyaistvennyh nauk Hafiza Mumindzhanova. - Ankara: Prodovolstvennaya i selskohozyaistvennaya organizatsiya obedinennyh natsii. - 174 p. (2016).

19 Natsionalnyiy energeticheskiy doklad 2017 g. dlya Respubliki Kazahstan: Ustoychivaya energetika dlya ustoychivoy ekonomiki. Proekt. IHS Markit. (2017).

20 Analiz rynka elektroenergii Kazakhstana. - Astana: Samruk Energy. Departament «Razvitie rynka». - yanvar. - 24 p. (2018).

21 D. E. Kalmykov. Kratkii gid po zelenoi economike. - Karaganda: EkoMuzei, CINEST. -32 (2017).

22 THE GLOBAL GREEN ECONOMY INDEX GGEI 2014. Measuring National. Performance in the Green Economy.4th Edition - October (2014).

$23 \mathrm{http}: / /$ www.oecd.org/greengrowth/48224574.pdf 
24 A. N. Turginbayeva, S. T. Abildaev. Quantitave assessment of regional economy competitiveness (Republic of Kazakhstan case study). Actual Problems of Economics.146(8), 477- 485 (2013). 